\title{
Aldabrachelys hololissa (Günther 1877) - Seychelles Giant Tortoise
}

\author{
JuSTin GerLaCH ${ }^{1}$ \\ ${ }^{1} 133$ Cherry Hinton Road, Cambridge, CB1 7BX United Kingdom [jstgerlach@aol.com]
}

Summary. - The Seychelles Giant Tortoise, Aldabrachelys hololissa (= Dipsochelys hololissa) (Family Testudinidae) is a controversial species possibly distinct from the Aldabra giant tortoise, A. gigantea $(=D$. dussumieri of some authors). The species is a morphologically distinctive morphotype, but has so far not been genetically distinguishable from the Aldabra tortoise, and is considered by many researchers to be either synonymous with or only subspecifically distinct from that taxon. It is a domed grazing species, differing from the Aldabra tortoise in its broader shape and reduced ossification of the skeleton; it differs also from the other controversial giant tortoise in the Seychelles, the saddle-backed morphotype A. arnoldi. Aldabrachelys hololissa was apparently extirpated from the wild in the 1800s and is now known only from 37 adults, including 28 captive, 1 free-ranging on Cerf Island, and 8 on Cousine Island, 6 of which were released in 2011 along with 40 captive bred juveniles. Captive reared juveniles show that there is a presumed genetic basis to the morphotype and further genetic work is needed to elucidate this.

DistRibution. - Seychelles. Restricted to the granitic islands, original distribution unknown, but possible populations on Cerf, Cousine, Fregate, Mahé, Praslin, Round, and Silhouette islands. A wild population was re-established on Cousine Island in 2011.

Synonymy. - Testudo hololissa Günther 1877, Dipsochelys hololissa, Aldabrachelys hololissa, Aldabrachelys gigantea hololissa, Dipsochelys dussumieri hololissa.

SubsPeCIES. - None.

Status. - IUCN 2011 Red List: Not Evaluated (proposed listing: Extinct in the Wild, EW). CITES: Appendix II (as Testudinidae spp.).

Taxonomy. - This Seychelles species was recognized as distinct and described as Testudo hololissa by Günther (1877). Subsequently Rothschild (1915) confused it with the Aldabra Giant Tortoise Aldabrachelys gigantea (= Dipsochelys dussumieri) due to the inclusion of an aberrant Aldabran tortoise in the type series of $T$. hololissa and the loss of the other two syntypes. The name was overlooked until 1982 (Bour 1982, 1984) as all variation among Aldabran and Seychelles tortoises was attributed to artifacts of captive diets (Arnold 1979). However, A. hololissa (as D. hololissa) was revalidated in a review of the genus in 1998 (Gerlach and Canning 1998) based on morphological, osteological, and preliminary DNA studies. Subsequent analysis of 5 mitochondrial and nuclear genes failed to identify sig-

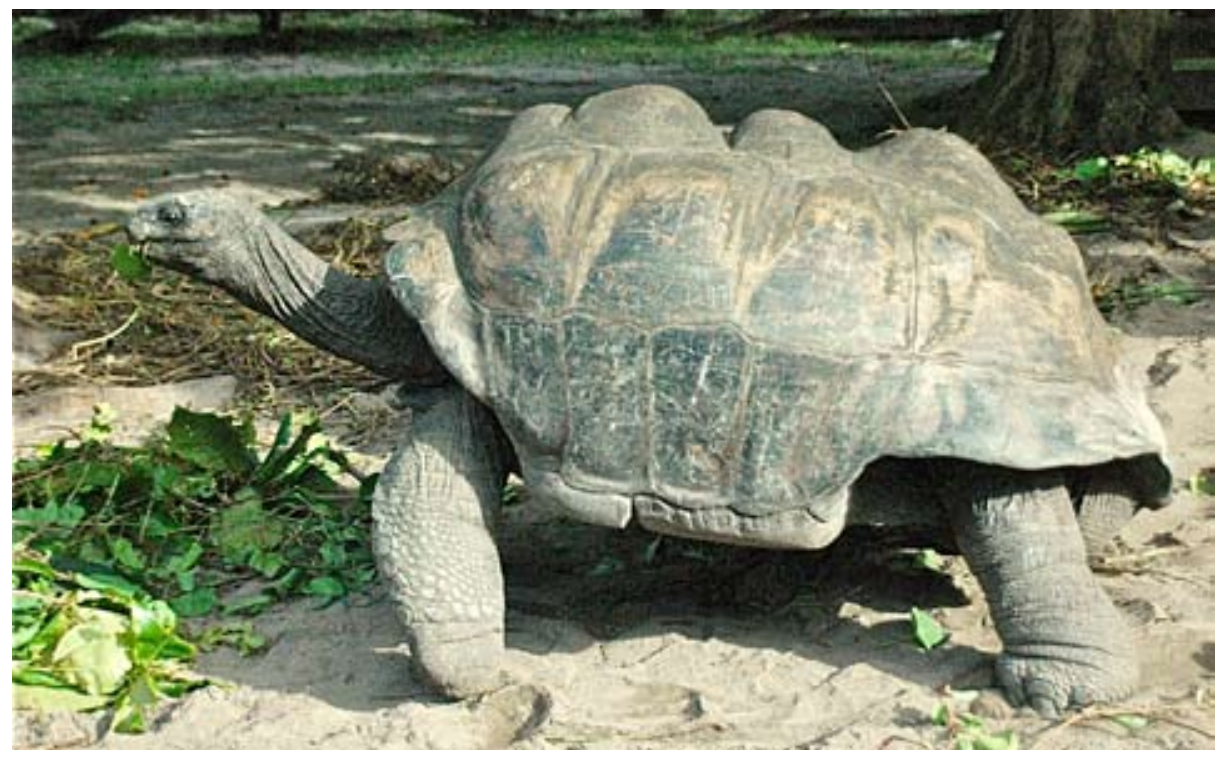

Figure 1. Adult male Aldabrachelys hololissa, Seychelles. Photo by Justin Gerlach. 


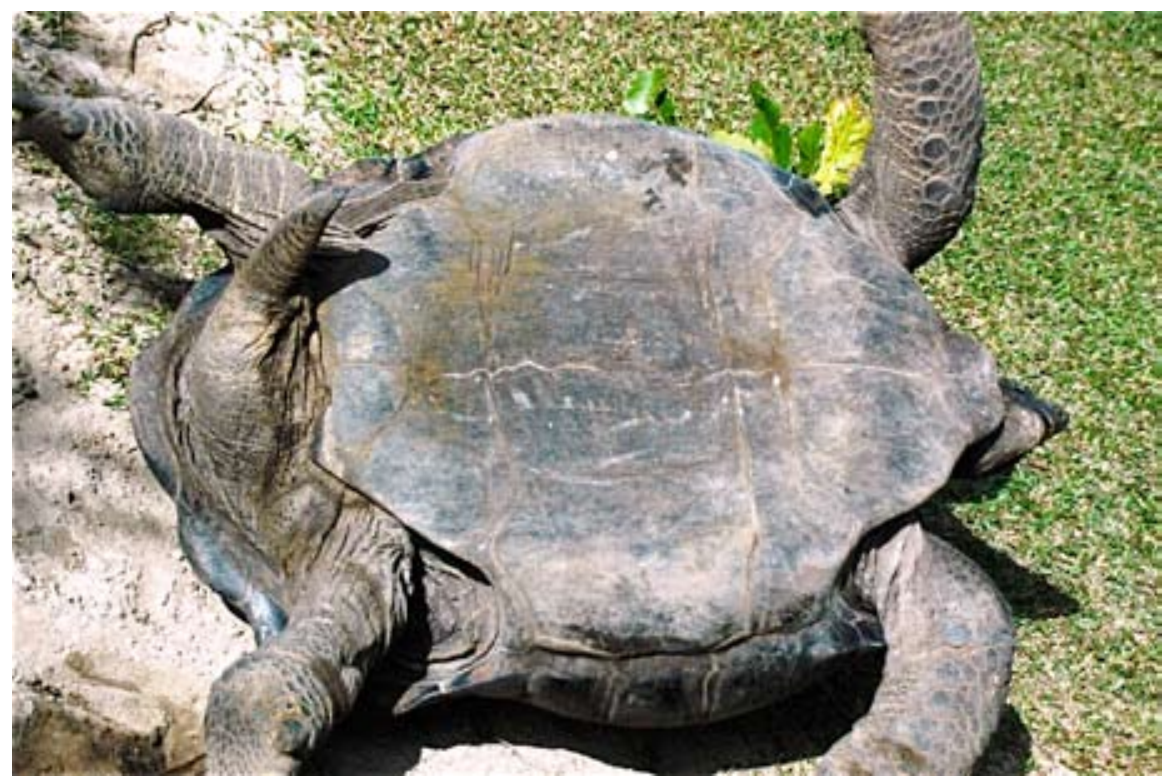

Figure 2. Adult male Aldabrachelys hololissa, Seychelles. Photo by Justin Gerlach.

nificant or consistent genetic differences among purported Aldabrachelys (= Dipsochelys) taxa (i.e., A. gigantea, A. hololissa, and A. arnoldi) (Austin et al. 2003; Palkovacs et al. 2002, 2003; Le et al. 2006; reviewed in Gerlach 2004, 2005). However, captive breeding under similar conditions has demonstrated that the morphological characteristics of the A. hololissa and A. arnoldi morphotypes are not due to environmental factors (Gerlach 2011). Further research is needed to identify the possible genetic distinctiveness underlying these morphotypes.

Not all authorities recognize the validity and distinctiveness of A. hololissa and A. arnoldi, and instead synonymize both with the Albabra tortoise, A. gigantea (= Dipsochelys dussumieri of some authors) (e.g., Palkovacs et al. 2002, 2003; Fritz and Havas 2007). However, others recognize these taxa as distinct as either species or subspecies of $A$. gigantea, based on the described morphological differences and incomplete genetic analysis (Gerlach and Canning 1998a, Gerlach and Bour 2003, Bour 2006, Turtle Taxonomy Working Group 2007, 2010; Leuteritz et al. 2008; Rhodin et al. 2008; Gerlach 2011).

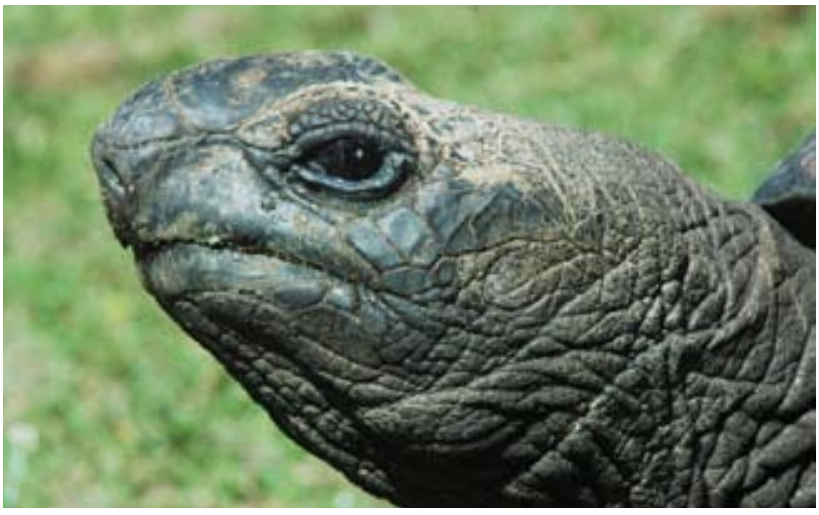

Figure 3. Adult male Aldabrachelys hololissa, Seychelles. Photo by Justin Gerlach.
Description. - The carapace of adults is domed but flattened dorsally, only slightly broader posteriorly than anteriorly, and has serrated marginals. A cervical (nuchal) scale is present. All vertebrals are broader than long with raised centers; vertebrals are usually elongate posteriorly, with 4 being the longest. Vertebral 3 is the highest point of the carapace, but it is only slightly higher than vertebrals 2 and 4 . There are 11 marginals, and the supracaudal (usually undivided) usually curves upwards slightly. The carapace and plastron are grayish-brown. The plastron is short to moderate (71-91\% of carapace length), and usually lacks an anal notch. If a notch is present it is very shallow (up to $5 \%$ of the anal length). The humero-pectoral suture is distinctly angled laterally. There is a large terminal scale on the tail of males. Males are the larger sex, reaching $138 \mathrm{~cm}$ straight carapace length as compared to $95 \mathrm{~cm}$ for females. Males have longer tails and a distinctly concave plastron. Hatchlings are pale gray, darkening to blackish brown over about a month (Gerlach and Bour 2003; Gerlach 2011).

The skull is distinctive in having broad, gradually sloping postorbitals, a large hour-glass shaped processus

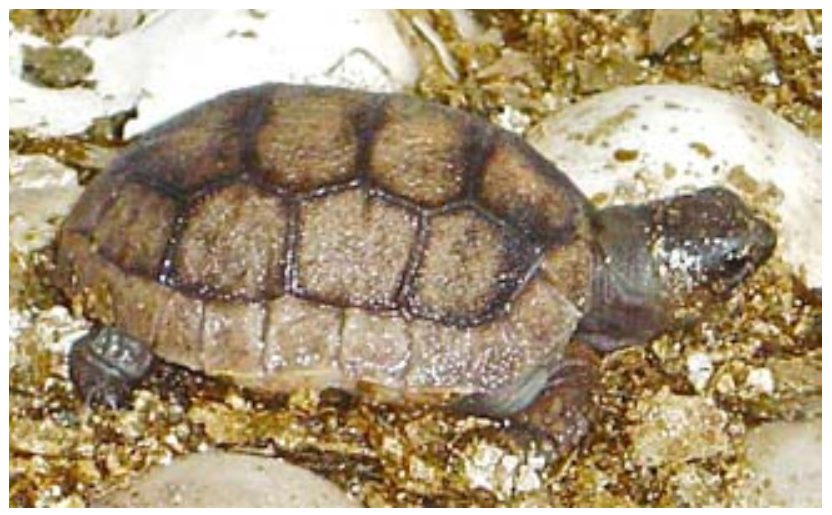

Figure 4. Hatchling Aldabrachelys hololissa, Seychelles. Photo by Justin Gerlach. 


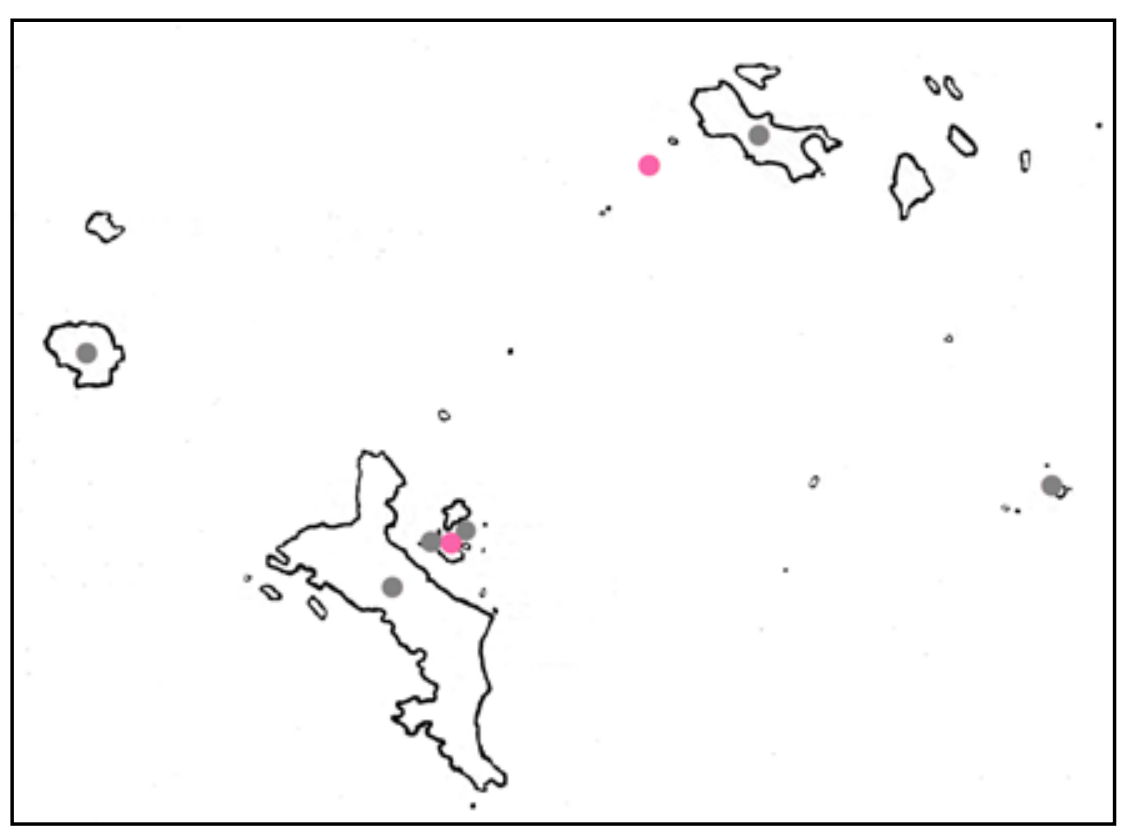

Figure 4. Distribution of Aldabrachelys hololissa in the Seychelles islands, east of Africa in the Indian Ocean. Purple dots = occurrence records of reintroduced populations based on author's data; gray dots = possible locations of extirpated populations based on author's data.

frontalis circumolfactorius, a well-developed anteriorly directed process on the upper posterior margin of the quadrate, reduced processus vomerinus dorsalis, and highly developed supraoccipital crest even in juveniles. In the lower jaw the articulars are truncated anteriorly. The post-cranial anatomy is typical of the genus except in having gradual shortening of the posterior costals (pleurals), a less obtuse angle between the main shaft of the scapula and the acromion process, a rounded coronoid fossa on the humerus, no distinct olecranon process on the ulna and no groove on the tibia. The first neural bone is a tapering hexagon, subsequent neurals are quadrilateral and convex with median projections from the costals (Gerlach 1999). The skeleton is usually unfused, even in old individuals, unlike the other Aldabrachelys species.

The differential diagnosis for the taxon is that it is a broad, domed giant tortoise with humero-pectoral suture angled laterally at $140-145^{\circ}$, extreme truncation of the articulars, postorbitals bowed posteriorly throughout their length, processus frontalis circumolfactorius large and regular in shape, acromion process at $100-115^{\circ}$ to the scapula, no olecranon process, and reduced fusion of skeletal elements. This species can be distinguished from A. gigantea $(=D$. dussumieri) in being broader, with a brown carapace, an angled humero-pectoral suture (instead of curved) and lacking a deep anal notch. It differs from $A$. arnoldi in being domed rather than saddle-backed and lacking the distinctive scute proportions of A. arnoldi (Gerlach 2004).

Distribution. - Endemic to the granitic Seychelles islands. Probably originally found on many islands, with evidence for populations on Cerf, Cousine, Fregate, Mahé, Praslin, Round, and Silhouette islands (Gerlach 2004, 2007). This species may have been sympatric with $A$. arnoldi, but this is speculative.
Now extinct in the wild since approximately the mid1800s. Reintroduced in the wild in 2002 and 2011 on Cousine Island with 8 adults and 40 juveniles. In addition there is one free-ranging adult on Cerf Island.

Habitat and Ecology. - Historical records suggest this species occurred in lowland grassland, scrub, and open woodland near streams and marshes. This agrees with studies of captive ecology and the behavior of the three free-range animals.

From 1 year of age juveniles show the flattened-dome morphology of adults (Gerlach 2011). Growth is rapid, reaching $15-20 \mathrm{~kg}$ after 5 years. The age at sexual maturity is not known; it is assumed to be $16-25 \mathrm{yrs}$ as in other $\mathrm{Al}$ dabrachelys species. Longevity is estimated to be over 100 yrs based on data from A. gigantea.

In captivity, mating occurs in December to March, and in good conditions up to four clutches may be laid each year, usually in July to September, each containing 14-21 eggs. The nest measures $30-35 \mathrm{~cm}$ deep, and is sock-shaped. Eggs are spherical and hard-shelled, weighing ca. $60 \mathrm{~g}$ each (mean $59.54 \mathrm{~g}$; range 54.3-65.2 g). Sex determination is temperature-dependent with males produced at $29-31^{\circ} \mathrm{C}$ after $113-133$ days and females at $31-33^{\circ} \mathrm{C}$ after $97-111$ days (Gerlach 2003, 2007).

This is a grazing species, feeding mainly on low growing vegetation or grass, with fallen leaves constituting $80 \%$ of the diet and grass $19 \%$ (Gerlach 2007). The species is active in the early morning and late afternoon.

Population Status. - The species has been extinct in the wild since the mid-1800s and is now known from only 37 adult animals. Currently there is one free-ranging male of unknown origin on Cerf Island and 8 adults and 40 juveniles on Cousine Island. The Cousine Island population was introduced to the island -2 males in 2002 and 4 males, 
2 females, and 40 juveniles in 2011 . In addition, 28 captive adults have been identified ( 27 males, 1 female).

Threats to Survival. - Historically threatened by exploitation for food and export. Habitat loss has not been significant as most wild populations had been lost before habitat destruction became significant. Currently the only active threats are the result of the restricted population, principally inbreeding. The adult sex ratio is male-biased (1:18) and there is only one breeding female. Juvenile sex ratio is balanced but is entirely descended from the single breeding pair.

Conservation Measures Taken. - All Aldabrachelys taxa are included on CITES Appendix II as Testudinidae spp. The species is not currently included on the IUCN Red List.

Eight free-ranging adults have been reintroduced to the Cousine Island Special Reserve. The species has been bred in captivity by the Nature Protection Trust of Seychelles 'Seychelles Giant Tortoise Conservation Project' between 1997 and 2011. This produced 40 juveniles which have also been released on Cousine Island.

Conservation Measures Proposed. - The IUCN Red List status should be Extinct in the Wild. Further reintroductions need to continue to take place to build a wild breeding population as quickly as possible (a first step in this direction was taken in 2011 with the reintroduction of 6 adults and 40 juveniles to Cousine Island).

Captive Husbandry. - The species has been bred in captivity by the Nature Protection Trust of Seychelles on Silhouette Island, Seychelles. A small number of captive individuals are known elsewhere, but none are in breeding groups. Successful breeding has required the use of large, natural enclosures, and the provision of abundant natural plant food. Social aspects are important for breeding. Egg incubation has been successful at $27-32^{\circ} \mathrm{C}$ and humidity of over $80 \%$.

Current Research. - Research on growth patterns and behavior is continuing. Detailed genetic research is needed to elucidate the genetic controls of the morphological features of this taxon, allowing its taxonomic status to be clarified.

Acknowledgments. - The initial genetic work on the Seychelles giant tortoises was supported by the Linnaeus Fund of the Chelonian Research Foundation. The captive breeding project was supported by the British Chelonia Group, Conservation International, and the Nederlandse Schildpadden Vereniging. Introduction to Cousine Island was undertaken with the support of Cousine Island.

\section{LITERATURE CITED}

ARNOLD, E.N. 1979. Indian Ocean giant tortoises: their systematics and island adaptations. Philosophical Transactions of the Royal Society, London B 286:127-145.

Austin, J.J., ARnOld, E.N., AND Bour, R. 2003. Was there a second adaptive radiation of giant tortoises in the Indian Ocean? Molecular Ecology 12:1396-1402.

Bour, R. 1982. Contribution à la connaisance des tortues terrestres des Seychelles: définition du genre endémique et description d'une espéce nouvelle probablement originaire des îles grantiques et bord de l'extinction. Comptes Rendus de l'Académie des Sciences 295:117-122.

BouR, R. 1984. Les tortues terrestres géantes des îles de l'Océan Indien occidental: données géographiques, taxinomiques et phylogénétiques. In: Broin, F. de and Jiménez-Fuentes, E. (Eds.). Studia Geologica Salmanticensia Vol. Especial 1. Studia Palaeocheloniologica 1:17-76.

Bour, R. 2006. Identity of Testudo gigantea Schweigger, 1812 and rediscovery of the type specimen. Emys 13:12-23.

FritZ, U. AND HaVAS, P. 2007. Checklist of chelonians of the world. Vertebrate Zoology 57(2):149-368.

GerLach, J. 1999. Distinctive neural bones in Dipsochelys giant tortoises. Journal of Morphology 240:33-38.

GerLach, J. 2003. Five years of conserving Seychelles Chelonia. Testudo 5:30-41.

Gerlach, J. 2004. Giant Tortoises of the Indian Ocean. Frankfurt am Main: Edition Chimaira, 207 pp.

GERLACH, J. 2005. Thermoregulation in captive Indian Ocean giant tortoises. Chelonian Conservation and Biology 4:937-941.

GerLach, J. (Ed.). 2007. Terrestial and Freshwater Vertebrates of Seychelles. Leiden: Backhuys Publishers, $154 \mathrm{pp}$.

GERLACH, J. 2011. Development of distinct morphotypes in captive Seychelles-Aldabra giant tortoises. Chelonian Conservation and Biology 10(1): 102-112.

GERLACH,J.AND BOUR, R. 2003. Morphology of hatchling Dipsochelys giant tortoises. Radiata 12:11-20.

Gerlach, J. And Canning, L. 1998a. Taxonomy of Indian Ocean giant tortoises (Dipsochelys). Chelonian Conservation and Biology 3:3-19.

GERLACH,J. ANDCANNING,L. 1998b. Identification of Seychelles giant tortoises. Linnaeus Fund research report. Chelonian Conservation and Biology 3:133-135.

GüNTHER, A.C.L.G. 1877. The gigantic land Tortoises (living and extinct) in the Collection of the British Museum. London: British Museum, 96 pp.

Le, M., Raxworthy, C.J., McCord, W.P., And Mertz, L. 2006. A molecularphylogeny of tortoises (Testudines: Testudinidae) based on mitochondrial and nuclear genes. Molecular Phylogenetics and Evolution 40:517-531.

Leuteritz, T.E., Gerlach, J., MittermeIer, R.A., Rhodin,A.G.J., VAN DiJK, P.P., LEWIs, R., AND RandRIAMAhazo, H. 2008. Turtles and Tortoises of Madagascar and Adjacent Indian Ocean Islands. Pocket Identification Guide. Arlington, VA: Conservation International, Tropical Pocket Guide Series, 19 pp.

Palkovacs,E.P.,Gerlach,J., ANDCACCONE,A. 2002.The evolutionary origin of Indian Ocean tortoises (Dipsochelys). Molecular Phylogenetics and Evolution 24:216-227.

Palkovacs,E.P.,Maschner, M.,Ciofi,C.,Gerlach,J., and Caccone, A. 2003. Are the native giant tortoises from the Seychelles really extinct? Molecular Ecology 12:1403-1414.

Rhodin, A.G.J., vAN DiJK, P.P., AND PARHAM, J.F. 2008. Turtles of the world: annotated checklist of taxonomy and synonymy. In: Rhodin, A.G.J., Pritchard, P.C.H., van Dijk, P.P., Saumure, R.A., Buhlmann, K.A. and Iverson, J.B. (Eds.). Conservation Biology of Freshwater Turtles and Tortoises: A Compilation Project of the IUCN/SSC Tortoise and Freshwater Turtle Specialist Group. Chelonian Research Monographs No. 5, pp. 000.1-000.38.

RotHSCHILD, W. 1915. On the gigantic land tortoises of the Seychelles and Aldabra-Madagascar group with some notes on certain forms of the Mascarene group. Novitates Zoologicae 22:418-442.

Turtle Taxonomy Working Group [Bickham, J.W., Iverson, J.B., 
Parham, J.F., Philippen, H.-D., Rhodin, A.G.J., Shaffer, H.B., SPINKS, P.Q., AND VAN DiJK, P.P. 2007. An annotated list of modern turtle terminal taxa with comments on areas of taxonomic instability and recent change. In: Shaffer, H.B., FitzSimmons, N.N., Georges,A., and Rhodin, A.G.J.(Eds.). Defining Turtle Diversity: Proceedings of a Workshop on Genetics, Ethics, and Taxonomy of Freshwater Turtles and Tortoises. Chelonian Research Monographs No. 4, pp. 173-199.

Turtle Taxonomy Working Group [Rhodin, A.G.J., van DiJk, P.P., IVERSON, J.B., AND SHAFFER, H.B.]. 2010. Turtles of the world, 2010 update: annotated checklist of taxonomy, synonymy, distribution, and conservation status. In: Rhodin, A.G.J., Pritchard, P.C.H., van Dijk, P.P., Saumure, R.A., Buhlmann, K.A., Iverson, J.B., and Mittermeier, R.A. (Eds.). Conservation Biology of Freshwater Turtles and Tortoises: A Compilation Project of the IUCN/SSC Tortoise and Freshwater Turtle Specialist Group. Chelonian Research Monographs No. 5, pp. 000.85-000.164, doi:10.3854/crm.5.000. checklist.v3.2010, http://www.iucn-tftsg.org/cbftt/.

\section{Citation Format for this Account:}

GerLach, J. 2011 . Aldabrachelys hololissa (Günther 1877) - Seychelles Giant Tortoise. In: Rhodin, A.G.J.,Pritchard, P.C.H., van Dijk, P.P., Saumure, R.A., Buhlmann, K.A., Iverson, J.B., and Mittermeier, R.A. (Eds.). Conservation Biology of Freshwater Turtles and Tortoises: A Compilation Project of the IUCN/SSC Tortoise and Freshwater Turtle Specialist Group. Chelonian Research Monographs No. 5, pp. 061.1-061.5, doi:10.3854/ crm.5.061.hololissa.v1.2011, http://www.iucn-tftsg.org/cbftt/. 